\title{
TINJAUAN PUSTAKA MENGENAI PERBEDAAN DERAJAT KECEMASAN MAHASISWA FAKULTAS KEDOKTERAN TAHAP PREKLINIK DAN KLINIK
}

\author{
Atica Ramadhani Putri ${ }^{1}$ \\ ${ }^{1}$ Pendidikan Dokter Fakultas Kedokteran Universitas Lampung

\section{Abstract : The Difference Of Degree Of Anxiety Between Preclinic And Clinic Students}

Anxiety is a psychiatric disorder that is often encountered and can be experienced by everyone in everyday life. Anxiety usually occurs when someone experiences or faces something that is out of routine such as just before the test, before giving a speech in front of the crowd, when the work environment or education changes, and in other situations. Medical students have higher stress levels than other faculty students. One of the factors that can make students stressful is the very high expectations from family and society. The habit of reading for hours in a day and the need to improve real health services in the field are factors that can cause stress too. In 2010 , around $4.5 \%$ of the global population had anxiety disorders, or around 273 million people, where women are more at risk than men, around $5.2 \%$ for women and $2.8 \%$ for men. In Indonesia there are approximately $39,106,283$ affected by anxiety disorders from around the population of $238,452,952$. The method used is a literature study based on the results of studies of various literatures various literatures that have proven their validity, relate to each other, are relevant to the study and the analysis of the discussion.

Keyword : Degree of anxiety, preclinic students, clinic students

\begin{abstract}
Abstrak : Perbedaan Derajat Kecemasan Mahasiswa Fakultas Kedokteran Tahap Preklinik Dan Klinik

Kecemasan merupakan salah satu gangguan kondisi kejiwaan yang sering ditemui dan dapat dialami setiap orang dalam kehidupan sehari-hari. Kecemasan biasa terjadi saat seseorang mengalami atau menghadapi suatu hal yang di luar rutinitas seperti sesaat sebelum ujian, sebelum memberikan pidato di depan orang banyak, pada saat perubahan lingkungan kerja atau pendidikan, dan pada situasi lainnya. Mahasiswa kedokteran cenderung memiliki tingkat stres lebih tinggi dibanding mahasiswa fakultas lain. Faktor-faktor yang dapat membuat stres mahasiswa salah satunya ialah harapan yang sangat tinggi dari keluarga dan masyarakat. Kebiasaan membaca selama berjam-jam dalam sehari dan kewajiban untuk memahami pelayanan kesehatan yang nyata di lapangan merupakan faktor yang dapat menyebabkan stres juga. Tahun 2010, sekitar 4,5\% dari populasi secara global memiliki gangguan kecemasan, atau sekitar 273 juta penduduk, dimana wanita lebih sering berisiko dibanding laki-laki, sekitar 5,2\% untuk wanita dan 2,8\% untuk laki-laki. Di Indonesia terdapat kurang lebih 39.106.283 yang terpengaruh dengan gangguan kecemasan dari sekitar populasi 238.452.952. Metode yang digunakan berupa studi pustaka yang didasarkan atas hasil studi terhadap berbagai literatur yang telah teruji validitasnya, berhubungan satu sama lain, relevan dengan kajian tulisan serta mendukung analisis pembahasan.
\end{abstract}

Kata Kunci : Derajat Kecemasan, mahasiswa preklinik, mahasiswa klinik

PENDAHULUAN

Masalah kesehatan mental merupakan salah satu masalah yang paling dikhawatirkan oleh masyarakat karena tingginya angka kejadian dari masalah tersebut, sulitnya pengobatan dan kecenderungan untuk menjadi kronik (Modi \& Kumar, 2013). 
Tahun 2010, sekitar 4,5\% dari populasi secara global memiliki gangguan kecemasan, atau sekitar 273 juta penduduk, dimana wanita lebih sering berisiko dibanding laki-laki, sekitar 5,2\% untuk wanita dan 2,8\% untuk laki-laki. Di Indonesia terdapat kurang lebih 39.106.283 yang terpengaruh dengan gangguan kecemasan dari sekitar populasi 238.452.952(Reinhart, Knight, Roberts, \& Mendes, 2012).

Beberapa hasil penelitian menunjukkan bahwa mahasiswa pada tingkat pendidikan yang lebih tinggi cenderung memiliki tingkat kasus gangguan kejiwaan yang lebih besar. Depresi dan gangguan kecemasan merupakan salah satu penyakit kejiwaan yang paling sering ditemukan (Ayu, Savitri, Ketut, \& Diniari, 2015; Elsenberg 2007).

Sudah terdapat laporan mengenai morbiditas psikologis di antara mahasiswa kedokteran dari beberapa penelitian di beberapa Negara Amerika dan Eropa, serta negara belahan dunia lainnya terutama mengenai kasus cemas dan depresi (Inam, Saqib, \& Alam, 2003).

Kecemasan merupakan salah satu gangguan kondisi kejiwaan yang sering ditemui dan dapat dialami setiap orang dalam kehidupan sehari-hari. Kecemasan biasa terjadi saat seseorang mengalami atau menghadapi suatu hal yang diluar rutinitas seperti sesaat sebelum ujian, sebelum memberikan pidato didepan orang banyak, pada saat perubahan lingkungan kerja atau pendidikan, dan pada situasi lainnya (Behar, DiMarco, Hekler, Mohlman, \& Staples, 2009; Elvira \& Sylvia, 2008).

Mahasiswa kedokteran cenderung memiliki tingkat stress lebih tinggi dibanding mahasiswa fakultas lain. Faktor-faktor yang dapat membuat stress mahasiswa salah satunya ialah harapan yang sangat tinggi dari keluarga dan masyarakat. Tak hanya itu, kebiasaan membaca selama berjam-jam dalam sehari dan kewajiban untuk memahami pelayanan kesehatan yang nyata di lapangangan merupakan faktor yang dapat menyebabkan stress juga (Ayu et al., 2015).

\section{METODE}

Metode yang digunakan berupa studi pustaka yang didasarkan atas hasil studi terhadap berbagai literatur yang telah teruji validitasnya, berhubungan satu sama lain, relevan dengan kajian tulisan serta mendukung analisis pembahasan.

Data-data yang digunakan bersumber dari berbagai referensi atau literatur yang relevan dengan topik permasalahan yang dibahas. Validitas dan relevansi referensi yang digunakan dapat dipertanggungjawabkan. Jenis data yang diperoleh berupa data sekunder yang bersifat kualitatif maupun kuantitatif.

\section{PEMBAHASAN}

Kecemasan merupakan proses normal dalam kehidupan seseorang, dimana kecemasan ini menjadi masalah ketika mengganggu aktivitas sehari-hari seseorang atau mengurangi kualitas hidup seseorang (Thinagar \& Westa, 2017).

Manifestasi atau gejala seseorang mengalami kecemasan dapat dibagi menjadi dua gejala yaitu gejala objektif seperti mual, sakit perut dan vertigo, dan gejala subjektif yang biasanya berhubungan dengan psikologi, antara lain gangguan pikiran, perasaan takut, dan lain-lain. Manifestasi perifer kecemasan antara lain takikardia, palpitasi, tremor, pusing, diare, kepala terasa ringan, hiperhidrosis, gelisah, hiperrefleksia, sinkop, hipertensi (Fajriati et al., 2018; Sadock \& Sadock, 2010).

Mahasiswa kedokteran lebih berisiko terkena gangguan kecemasan yang dapat menurunkan kualitas hidupnya, antara lain menurunkan konsentrasi dalam proses pembelajaran dimana hal ini berkaitan dengan pencapaian prestasi belajar yang rendah yang nantinya dapat memicu terjadinya depresi (Thinagar \& Westa, 2017). 
Selama menjalani pendidikan kedokteran, stres yang dialami mahasiswa dapat menjadi faktor pencetus gangguan kesehatan jiwa dan tentunya memiliki akibat negatif pada fungsi kognitif dan pembelajaran mahasiswa (Modi \& Kumar, 2013).

Stres ialah suatu fenomena yang tidak dapat dihindari dan sering terjadi dalam kehidupan sehari-hari dan akan dialami oleh setiap orang (Purwati, 2012).

Berbagai penelitian telah menunjukkan bahwa mahasiswa kedokteran lebih cenderung mengalami stres yang tinggi dibandingkan mahasiswa program studi di sektor non medis (Legiran, Zalili dan Bellinawati, 2015).

Mahasiswa sangat rentan mengalami stres, khususnya stres akademik yang bisa bersumber dari tugas yang terlalu banyak, tuntutan yang saling bertentangan, kebisingan, situasi yang monoton, harapan yang mengada-ngada, tidak dihargai, diacuhkan, kehilangan kesempatan, dan kurang adanya kontrol terhadap diri (Purwati, 2012).

Pada penelitian yang dilakukan Abdulghani pada mahasiswa kedokteran tahun pertama di Arab Saudi ditemukan sebesar 74.2 persen mahasiswa kedokteran tahun pertama mengalami stres tinggi, dan pada tahun berikutnya prevalensinya menurun menjadi 69.8 persen dan 48.6 persen (Oktovia, dkk. 2012). Kemudian pada tahun 2006, penelitian yang dilakukan oleh Stephani terhadap mahasiswa kedokteran di Universitas California, Amerika dan didapati sekitar 51 persen mahasiswa mengalami stres (Suganda, 2014).

Dampak psikologis dari stres pada mahasiswa dapat berupa dampak negatif dan dampak positif. Dampak negatif dari stres antara lain demotivasi diri, penurunan konsentrasi dan pemusatan perhatian selama kuliah, penurunan minat, bahkan dapat menimbulkan perilaku kurang baik seperti sengaja terlambat datang ketika kuliah, dan sebagainya. Sedangkan dampak positifnya antara lain berupa peningkatan kreativitas dan memicu pengembangan diri, selama stres yang dialami masih dalam batas kapasitas individu tersebut. (Moffat et al., 2004; Abdulghani, 2008).

Stressor pada mahasiswa kedokteran terdiri dari enam kelompok, yaitu stressor terkait akademik, stressor terkait hubungan interpersonal dan intrapersonal, stressor terkait hubungan belajar-mengajar, stressor terkait hubungan sosial, stressor terkait keinginan dan pengendalian, serta stressor terkait aktivitas kelompok.

Pada penelitian yang dilakukan (Rahmayani, Liza, \& Syah, 2019) tingkat stres terkait akademik yang terbanyak adalah tingkat stres berat, sedangkan tingkat stres terkait hubungan intrapersonal dan interpersonal yang terbanyak adalah tingkat stres berat, kemudian tingkat stres terkait hubungan belajarmengajar yang terbanyak adalah tingkat stres sedang, lalu tingkat stres terkait hubungan sosial yang terbanyak adalah tingkat stres sedang, kemudian tingkat stres terkait keinginan dan pengendalian yang terbanyak adalah tingkat stres sedang, terakhir tingkat stres terkait aktivitas kelompok yang terbanyak adalah tingkat stres sedang, lalu dapat disimpulkan stressor yang paling menyebabkan stres adalah stres terkait hubungan intrapersonal dan interpersonal.

Pada penelitian yang dilakukan oleh (Ayu et al., 2015) yang berjudul "Perbedaan Tingkat Kecemasan Dan Depresi Pada Mahasiswa Jenjang Preklinik Dan Co-Asisten Di Fakultas Kedokteran Universitas Udayana" melalui analisa uji software didapatkan nilai kemaknaan $\mathrm{p}$ untuk kecemasan adalah $p=0,000(<0,005)$, dimana hal ini menunjukkan bahwa terdapat perbedaan derajat kecemasan yang bermakna antara mahasiswa pendidikan dokter tahap preklinik dan koasisten.

Perbedaan tingkat kecemasan yang bermakna di antara kelompok mahasiswa preklinik dan klinik ini dipengaruhi oleh berbagai faktor. 
Faktor-faktor tersebut antara lain tuntutan untuk lebih aktif dalam menuntut ilmu terutama pada tahap klinik yang memiliki tanggung jawab serta beban yang lebih berat dibanding tahap preklinik, waktu yang lebih padat terjadwal di tahap klinik dibanding tahap preklinik, yang dimana mahasiswa cenderung lebih menghabiskan waktu di ruang kuliah, suasananya yang jauh lebih kompetitif pada tahap klinik di banding pada tahap preklinik, serta materi yang diajarkan lebih aplikatif dan sangat luas yang menuntut mahasiswa tahap klinik untuk memiliki keterampilan yang merupakan bekal dari tahap klinik (Basnet, Jaiswal, Adhikari, \& Shyangwa, 2012).

Pada tahun 2010, penelitian yang dilakukan oleh Yuke yang berjudul "Perbedaan Derajat Kecemasan dan Depresi Mahasiswa Kedokteran Preklinik dan Koasisten di FK UNS Surakarta" menunjukkan hasil bahwa terdapat perbedaan derajat kecemasan dan depresi yang bermakna antara mahasiswa tahap preklinik dan tahap klinik. Pada penelitian didapatkan $p=0,002$ untuk uji statistik kecemasan yang menunjukkan bahwa hasil tersebut memiliki makna (Yuke, 2010). Namun pada tahun 1999, penelitian yang dilakukan oleh Suryo Wibowo memiliki hasil yang berbeda, dimana pada penelitian tersebut disimpulkan bahwa tidak terdapat perbedaan bermakna pada tingkat kecemasan pada mahasiswa preklinik dan mahasiswa koasisten. Tetapi perbedaan hasil ini dapat disebabkan karena metode penelitian yang dipakai berbeda, dan juga kriteria inklusi yang dipakai oleh Suryo Wibowo adalah mahasiswa yang baru menjalani kepaniteraan selama satu tahun.

Pada penelitian yang dilakukan Fajriati tahun 2015 yang meneliti perbedaan derajat kecemasan pada mahasiswa baru preklinik dan klinik Fakultas Kedokteran Universitas Andalas, memiliki hasil yang menunjukkan terdapat perbedaan derajat kecemasan pada mahasiswa preklinik dan klinik Universitas Andalas, namun tidak didapatkan perbedaan bermakna antara derajat kecemasan pada mahasiswa baru preklinik dan klinik Fakultas Kedokteran Universitas Andalas secara statistik. Tetapi hasil ini juga dapat dipengaruhi oleh variabel yang dipakai peneliti yaitu mahasiswa baru tahap preklinik (Fajriati et al., 2018).

\section{KESIMPULAN}

Terdapat perbedaan derajat kecemasan mahasiswa tahap preklinik dan tahap klinik Fakultas Kedokteran.

\section{DAFTAR PUSTAKA}

Abdulghani HM. (2008). Stress and depression among medical students: a cross sectional study at Medical College in Saudi Arabia. Pakistan Journal Medical Science, 24, 12-7.

Ayu, I., Savitri, R., Ketut, N., \& Diniari, S. (2015). Perbedaan Tingkat Kecemasan Dan Depresi Pada Mahasiswa Jenjang Preklinik Dan Co -Asisten Di Fakultas Kedokteran Universitas Udayana Pada Tahun 2014. E-Jurnal Medika Udayana, 4(7).

Basnet, B., Jaiswal, M., Adhikari, B., \& Shyangwa, P. M. (2012). Depression among undergraduate medical students. Kathmandu University Medical Journal, 10(39), 56-59.

Behar, E., DiMarco, I. D., Hekler, E. B., Mohlman, J., \& Staples, A. M. (2009). Current theoretical models of generalized anxiety disorder (GAD): Conceptual review and treatment implications. Journal of Anxiety Disorders, 23(8), 1011-1023.

Daniel Elsenberg Ph.d. (2007). Prevalence and Correlates of Depression, Anxiety and Suicidality Among University Student. American Journal of Orthopsychiatry, 77, 534-42. 
Elvira, Sylvia D. (2008). Gangguan panik. Jakarta. Balai Penerbit FKUI ,hlm.1-2.

Fajriati, L., Yaunin, Y., \& Isrona, L. (2018). Perbedaan Derajat Kecemasan pada Mahasiswa Baru Preklinik dan Klinik Fakultas Kedokteran Universitas Andalas. Jurnal Kesehatan Andalas, 6(3), 546-551.

Inam, S. N., Saqib, A., \& Alam, E. (2003). Prevalence of anxiety and depression among medical students of private university. JPMA. The Journal of the Pakistan Medical Association, 53(2), 4447.

Legiran, A., M. Zalili., Bellinawati, Nedya. (2015) Faktor Resiko Stres dan Perbedaannya pada Mahasiswa Berbagai Angkatan di Fakultas Kedokteran Universitas Muhammadiyah Palembang. Jurnal Kedokteran dan Kesehatan, 2(2), 197-202.

Modi, K., \& Kumar, D. (2013). Anxiety and depression in medical students and its association with coping method adopted by them. Indian Journal of Research and Reports in Medical Sciences, 3(2), 20-22.

Moffat KJ, McConnachiel A, Ross S, Morrison JM. (2004). First year medical student stress and coping in a problem-based learning medical curriculum. Medical Education, 38(3), 482-91.

Oktovia, W., dkk. (2012). Hubungan Kecerdasan Emosional Dengan Tingkat Stres Pada Mahasiswa Tahun Pertama Fakultas Kedokteran Universitas Riau. Universitas Riau, hlm. 2.

Purwati S. (2012). Tingkat stres akademik pada mahasiswa reguler angkatan 2010 Fakultas Ilmu Keperawatan Universitas Indonesia [Skripsi]. Depok: Fakultas Ilmu Keperawatan Universitas Indonesia.

Rahmayani RD, Rini GL, Nur AS. (2019). Gambaran Tingkat Stres
Berdasarkan Stressor pada Mahasiswa Kedokteran Tahun Pertama Program Studi Profesi Dokter Fakultas Kedokteran Universitas Andalas Angkatan 2017. Jurnal kesehatan andalas, 8(1).

Reinhart, L., Knight, W., Roberts, L., \& Mendes, C. (2012). HHS Public Access Global Burden of Disease Study 2010. Lancet, 380(9859), 2163-2196.

Sadock BJ, Sadock VA. (2010). Kaplan \& Sadock's: concise tektbook of clinical psychiatry. Edisi ke-3. Philadelphia USA. Lippincott Williams \& Wilkins, hlm. 236.

Suganda, K.D. (2014). Tingkat Stres Pada Mahasiswa Tahun Pertama Fakultas Kedokteran Universitas Sumatera Utara Angkatan 2013, Universitas Sumatera Utara, hlm. 2-3.

Thinagar, M., \& Westa, W. (2017). Tingkat kecemasan mahasiswa kedokteran Universitas Udayana dan implikasinya pada hasil ujian. Directory of Open Access Journals, 8(3), 181-183. 2

Wahyu Widosari Y. (2010). Perbedaan Derajat Kecemasan dan Depresi Mahasiswa Kedokteran Preklinik dan Koasisten di FK UNS Surakarta. Surakarta, 1-44. 